\title{
FLUID AND ELECTROLYTE REQUIREMENTS OF NEWBORN INFANTS WITH INTESTINAL OBSTRUCTION
}

BY

\author{
ALEXANDER PEONIDES, WINIFRED F. YOUNG and VALENTINE A. J. SWAIN \\ From the Queen Elizabeth Hospital for Children, London
}

(RECEIVED FOR PUBLICATION OCTOBER 30, 1962)

The findings in a consecutive series of 120 children of all ages treated with parenteral fluid therapy in support of major abdominal surgery have been reported (Young, McIntosh, Swain and Levin, 1959). The series included 23 newborn infants with intestinal obstruction. The plan of fluid therapy used was designed to replace initial deficits of water and electrolytes, to provide water, electrolytes and calories for maintenance, and to replace further abnormal losses after operation. This plan is now supported by the findings from balance studies on three older children with ileal obstruction in that series and by similar observations reported previously (Lowe, Rourke, MacLachlan and Butler, 1950; Holliday, Wallace and Stapleton, 1958). However, the newborn infants' requirements of fluid and electrolytes remain controversial, and some surgeons (Gross, 1953; Santulli, 1954; Rickham, 1957; Wilkinson, 1960) have advised less water and electrolytes than are recommended in the plan, preferring to keep such infants 'on the dry side'. On the other hand, Swenson (1958) and Grob (1960) include infants 1-2 days old in emphasizing that dehydration should be corrected before operation, and Colle and Paulsen (1959) consider that the assessment of volumes required for maintenance should be based upon the average normal oral intake from day to day during the first week of life, which is also recommended in this plan (Fig. 1). These authors were unable to demonstrate a fall in urine flow even in the early phase after surgery in newborns, Calcagno, Rubin and Singh (1955) in infants a few weeks old, and Young et al. (1959) in older children, although adults usually pass very little urine on the first day after operation (Le Quesne and Lewis, 1953; Le Quesne, 1957; Black, 1957).

\section{Water}

It is especially important to give newborn infants enough water to promote a free flow of urine, since their kidneys function less efficiently and with greater deterioration under stress than those of older subjects (McCance, 1948). When the intake of water is restricted, the glomerular filtration rate falls with the urine volume (McCance and Widdowson, 1954), so that infants becoming dehydrated are unable to excrete nitrogen and other metabolites from protein breakdown, including potassium. Stress at birth, or after birth, from respiratory distress or progressive dehydration accelerates this breakdown, and either acidosis or hyperkalaemia may then be lethal. Thus, fluid therapy which restores and maintains the glomerular filtration rate (gauged by a high urine flow) is particularly needed at times of stress in order to improve and maintain the excretion of nitrogen, potassium and

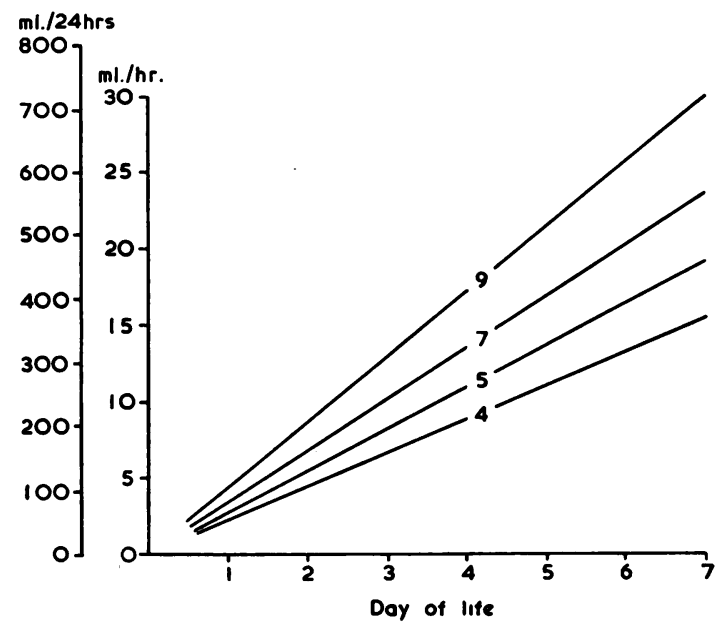

Fig. 1.-Volume (per 24 hours and per hour) of maintenance infusions graduated in increments of one-seventh per day towards the full requirements at seven days, according to birth weight.

(Figures in centre of lines indicate birth weight in $\mathrm{lb}$. ) 
acid metabolites. Furthermore, calories for metabolism from the glucose in the solutions used will diminish protein katabolism and therefore the metabolic products demanding excretion. At the same time great care must be taken to avoid giving excessive amounts of fluid to newborn infants who are unable to dilute their urine in response to a water load as efficiently as adults (Heller, 1951).

\section{Electrolytes}

Previously, Young et al.(1959) discussed the reasons for early adequate treatment of electrolyte depletion in patients undergoing abdominal surgery. The risk of oedema in newborns from over-retention of salt, which may only be partly renal in origin (Dean and McCance, 1949; McCance and Widdowson, 1957), and also the liability of premature infants to oedema and sclerema beginning before any significant addition of water and salt, are often taken too much into consideration in prescribing for patients at this age. The management of cases with the latter tendency needs separate consideration, for they cannot be treated successfully unless the distribution of their body fluids improves spontaneously. In fact, restoration of electrolyte losses in newborns is even more important than in older patients since their renal excretory capacity is lower and therefore episodes of salt depletion are more hazardous. Solutions of sodium chloride for replacement are needed by infants with a history of vomiting, and since such losses cannot be assessed accurately, an excess must usually be prescribed to ensure complete repair. Over-retention of sodium promotes potassium loss and augments any potassium deficit due initially to vomiting, dehydration or perhaps the stress of surgery. Administration of potassium promotes excretion of sodium and is also needed to restore any deficit of itself. It should be given as early in treatment as is consistent with safety, and this can be gauged by restoration of the urine flow, or often before this by finding a normal concentration of potassium in the plasma. Rickham (1957) considers that potassium is not usually needed for repair, since the losses from the stress of surgery appeared to be absent or negligible in his patients, the amount of potassium relative to nitrogen in their urine not exceeding that derived from protein breakdown. However, his patients were passing little urine, which would have diminished the output of potassium in this phase (McCance and Widdowson, 1954), and therefore this observation does not exclude losses at higher rates of urine flow. In either case, potassium should be given in order to avoid the retention of sodium and potassium depletion resulting from administration of excess sodium salts, since sodium over-retention, as already discussed, is a special hazard in the early days of life.

The management of fluid therapy is acknowledged to be difficult in newborn infants, but restoration of the body fluids may greatly improve the prognosis after surgery for intestinal obstruction. It was therefore decided to make further detailed observations in this group of patients including balance studies whenever possible, in order to evaluate the treatment and modify it if necessary for future cases. The most useful results have been obtained from balance studies in a few cases, but relevant information has also been obtained from measuring (a) the composition of aspirated gastro-intestinal fluid and (b) the daily output of electrolytes in the urine in some further cases and from observing the progress of all the patients in a consecutive series.

\section{Methods}

The plan for intravenous fluid therapy which has been used at the Queen Elizabeth Hospital for Children since 1953 is summarized in Table 1 and Fig. 1. It is adapted to the needs of the individual case from hour to hour according to clinical condition and laboratory findings. Antibiotics (usually penicillin or streptomycin) and vitamins are given intramuscularly or intravenously during the period of infusion.

Collection and measurement of the output, as urine and aspirated gastro-intestinal fluid, were arranged as before (Young et al., 1959). The solutions used for intravenous infusions were prepared by the hospital pharmacist and checked by analysis from time to time. At first the reconstituted dried plasma used was assumed to contain $\mathrm{Na} 140, \mathrm{~K} 5$, and $\mathrm{Cl} 100 \mathrm{mEq} /$ litre, but analysis during later experiments showed higher concentrations of sodium and potassium. Thus, in cases where analysis of the intake was omitted, the retention of electrolytes calculated by subtracting the output is likely to have been slightly underestimated. Small amounts of glucose and electrolyte solutions given orally towards the end of the balance periods were carefully measured and included in the intake.

The balance periods were usually continued until bowel function was restored with return of bowel sounds and passage of faeces, plugs of meconium being disregarded. Balance studies were sometimes terminated before bowel function had been restored, for example, in one case owing to loss of urine and, in another, when protein digest solutions had been given. Since a fraction of these amino acids would have been excreted directly into the urine, the ratio of potassium to nitrogen in the urine could not then be used to calculate potassium derived from endogenous metabolism.

The laboratory techniques were the same as those used previously (Young et al., 1959). 
TABLE 1

INTRAVENOUS FLUID THERAPY FOR NEWBORN INFANTS WITH INTESTINAL OBSTRUCTION

\begin{tabular}{|c|c|c|c|c|c|c|c|c|}
\hline \multirow{3}{*}{ Infusion } & \multicolumn{2}{|c|}{ Volume (ml.) } & \multirow{3}{*}{$\underset{\text { (hrs.) }}{\text { Duration }}$} & \multirow{3}{*}{$\begin{array}{l}\text { Composition of } \\
\text { Electrolyte Solutions } \\
\text { in } 5 \% \text { Dextrose }\end{array}$} & \multirow{2}{*}{\multicolumn{3}{|c|}{$\begin{array}{l}\text { Electrolytes } \\
\text { (mEq per kg.) }\end{array}$}} & \multirow{3}{*}{ Remarks } \\
\hline & \multirow{2}{*}{$\begin{array}{l}\text { Per kg. } \\
\text { Birth } \\
\text { Weight }\end{array}$} & \multirow{2}{*}{$\begin{array}{c}\text { Per lb. } \\
\text { Birth } \\
\text { Weight }\end{array}$} & & & & & & \\
\hline & & & & & $\mathrm{Na}$ & $\mathbf{K}$ & $\mathrm{Cl}$ & \\
\hline $\begin{array}{lll}\text { Initial } & \ldots & \ldots\end{array}$ & $\begin{array}{c}66 \\
\text { or less }\end{array}$ & $\begin{array}{l}30 \\
\text { or less }\end{array}$ & $\begin{array}{l}\text { Four or less if } \\
\text { (1) urine is } \\
\text { passed freely; } \\
\text { (2) emergency } \\
\text { surgery }\end{array}$ & $\begin{array}{l}\text { Half isotonic saline } \\
77 \mathrm{mEq} / \mathrm{l}\end{array}$ & $4 \cdot 8$ & - & $4 \cdot 8$ & $\begin{array}{l}\text { Isotonic saline if } \mathrm{Na} \text { level in } \\
\text { plasma is low }\end{array}$ \\
\hline During surgery & \multicolumn{3}{|c|}{ As indicated } & $\begin{array}{l}\text { Plasma (diluted or } \\
\text { full strength) } \\
\text { Blood only to replace } \\
\text { blood losses }\end{array}$ & & & & \\
\hline $\begin{array}{c}\text { Maintenance at age } \\
7 \text { days }^{*}\end{array}$ & $165-198$ & $75-90$ & 24 & $\begin{array}{l}\text { One-fifth isotonic } \\
\text { saline } 31 \mathrm{mEq} / 1 . \\
\mathrm{K} \text { salts }(\mathrm{KCl} \text { or } \mathrm{K} \\
\text { acetate) } 20 \mathrm{mEq} / \mathrm{l} .\end{array}$ & $5 \cdot 0-6 \cdot 1$ & $3 \cdot 3-4 \cdot 0$ & $\begin{array}{c}8 \cdot 3-10 \cdot 1 \\
\text { if } \mathrm{KCl} \\
\text { added } \\
5 \cdot 0-6 \cdot 1 \\
\text { if } \mathrm{K} \\
\text { acetate } \\
\text { added }\end{array}$ & $\begin{array}{l}\text { If oral feeding delayed more } \\
\text { than } 2 \text { days after surgery, } \\
\text { plasma (diluted to one- } \\
\text { quarter in } 5 \% \text { dextrose } \\
\text { solution) or protein digests } \\
\text { in } 5 \% \text { dextrose and appro- } \\
\text { priate electrolyte solutions }\end{array}$ \\
\hline Replacement & \multicolumn{2}{|c|}{$\begin{array}{l}\text { Equals that of } \\
\text { aspirated gas- } \\
\text { tro-intestinal } \\
\text { fluids includ- } \\
\text { ing 'pool' at } \\
\text { surgery }\end{array}$} & Varies & $\begin{array}{l}\text { Isotonic saline }+K \\
\text { salts as for main- } \\
\text { tenance }\end{array}$ & & & & $\mathrm{K}$ salts omitted if oliguric \\
\hline
\end{tabular}

* Graduation of amounts of infusions for infants of 1-7 days old is shown in Fig. 1.

\section{Material}

Between 1957 and 1960, a consecutive series of 24 newborn infants with intestinal obstruction treated according to the plan has been studied, but material for balance data was collected successfully from only five male infants, all of whom had duodenal obstruction. An infant with dehydration associated with oesophageal atresia was similarly investigated in order to compare the findings from a patient without previous loss of gastro-intestinal secretions with those from the cases of intestinal obstruction.

Each patient was given intravenous infusions before surgery, which was performed within 24 hours of admission, except in one patient with incomplete obstruction of the ileum due to bands, in whom operation was delayed for three days.

\section{Results}

Clinical Course. Of the 24 infants, 21 survived and three died, each of whom had obstruction to the small bowel. Table 2 shows the site and cause of obstruction, associated abnormalities and the outcome in these 24 patients. Their birth weights ranged from $3 \mathrm{lb} .3 \mathrm{oz}$. $(1.45 \mathrm{~kg}$.) to $8 \mathrm{lb} .10 \mathrm{oz}$. $(3.9 \mathrm{~kg}$.), and age on admission from 2 hours to 11 days. Hydration was assessed clinically, the incidence of dehydration at presentation (Table 3) being much greater among those where diagnosis was delayed beyond two days. The dehydrated patients had lost between 9 and $22 \%$ of their birth weight, but since different scales were used, the recorded amount of weight lost was of little value in assessing subsequent requirements for rehydration, which was judged mainly by the clinical and laboratory findings.

Of the 21 cases who survived, 11 recovered uneventfully; seven showed complications possibly related to parenteral fluid therapy and three due to alimentary dysfunction. Among the former, localized twitching occurred within 24 hours of operation in three, but this was attributed to anoxia from pulmonary collapse after inhalation of vomit in one, and in another, to hypocalcaemia which responded to calcium gluconate intravenously. In the third, twitching of longer duration was thought to be due either to water intoxication (serum sodium 125 $\mathrm{mEq} / \mathrm{l}$.) or hypocalcaemia (serum calcium $6 \cdot 3$ mg./100 ml.). One infant had signs of cerebral irritation (opisthotonus and hypertonia) without obvious cause, which regressed without special treatment. Three infants had sequelae due to infection from the intravenous infusions, despite prophylactic penicillin and streptomycin given intramuscularly. Phlebitis at the site of the infusion occurred in one (due to a Staph. pyogenes resistant to penicillin and streptomycin) and osteomyelitis in two infants. One of these whose right elbow and cervical vertebrae were affected had had an umbilical stump infected with a Staph. pyogenes as well as a mild thrombophlebitis; in the other case the right 
TABLE 2

SITE AND CAUSE OF OBSTRUCTION AND RECOVERY RATE IN 24 CASES

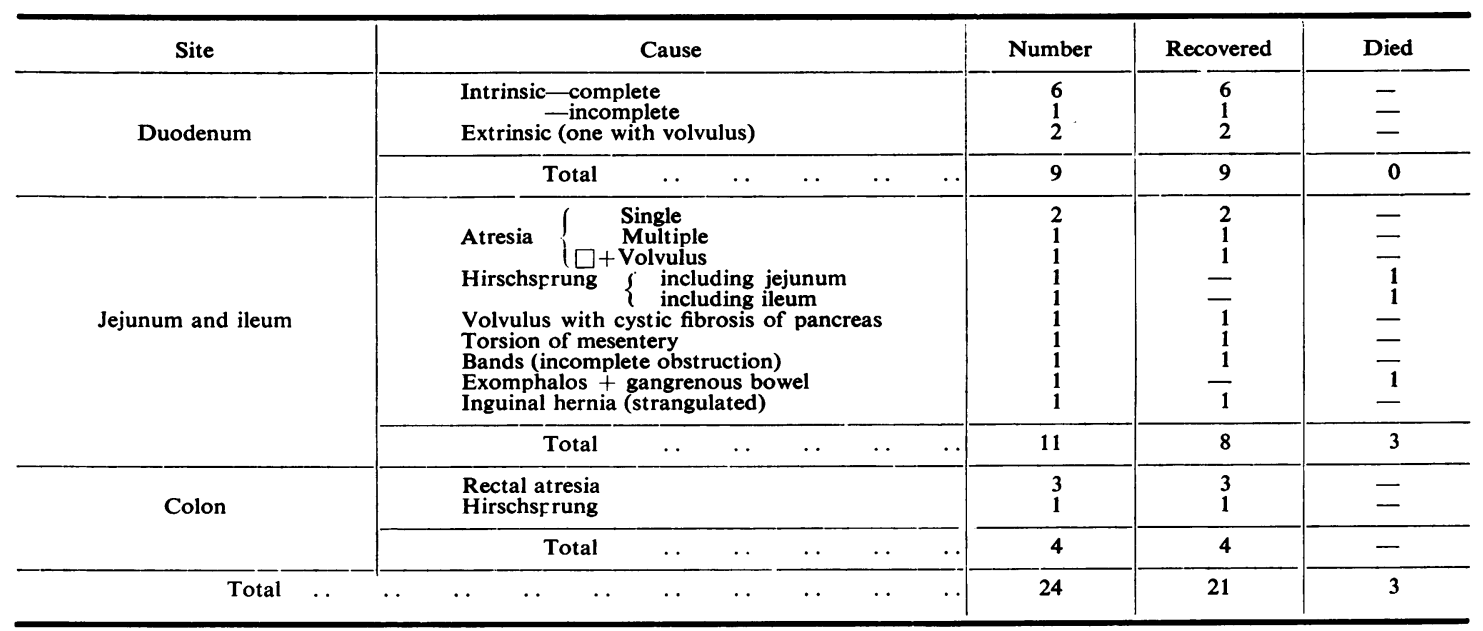

femur was involved. Large doses of antibiotics other than penicillin and streptomycin were given to both of these patients, and their bones have healed without serious residual deformity.

Two of the infants with alimentary dysfunction had diarrhoea from intestinal hurry, in one persisting for three months and in the other for only two weeks, but followed by chronic malabsorption with persistent steatorrhoea; the third had symptoms from a segment of dilated bowel, shown radiologically to be above the anastomosis, for two and a half months. The later course of these three patients is described elsewhere (Swain, Peonides and Young, 1963).

Three infants died, two while still receiving intravenous fluid therapy, and one at a later stage. One of two with Hirschsprung's disease had aganglionic bowel reaching the jejunum and died six days after surgery, two laparotomies having showed no obvious cause for the obstruction. The ileum was involved in the other who died aged 2 months, following a diagnostic laparotomy and then a high ileostomy. Tetany, occurring immediately after

TABLE 3

INCIDENCE OF DEHYDRATION IN RELATION TO AGE

\begin{tabular}{|c|c|c|c|}
\hline & \multirow{2}{*}{ Number } & \multicolumn{2}{|c|}{ Age on Admission } \\
\hline & & 2 days or less & More than 2 days \\
\hline Dehydrated & 9 & 2 & 7 \\
\hline Not dehydrated & 15 & 9 & 6 \\
\hline
\end{tabular}

both operations, was treated successfully with calcium given intravenously and inhalations of carbon dioxide and the patient was sustained by oral feeding from the fifth post-operative day. The ileostomy worked satisfactorily for two to three weeks, but malabsorption led to progressive deterioration in nutrition and he died from a terminal pneumonia.

A premature baby (birth weight $3 \mathrm{lb}$. $3 \mathrm{oz}$. $(1.45 \mathrm{~kg}$.)) with exomphalos complicated by gangrene of the ileum, died five days after $53 \mathrm{~cm}$. of bowel had been resected and an end-to-end anastomosis performed. Ileus had persisted with pooling of intestinal fluids followed by oliguria with water retention. Renal function may have deteriorated from incomplete replacement of salt during the 'pooling' phase. The sodium level in the plasma was low, $124 \mathrm{mEq} / \mathrm{l}$., and the potassium high, $7 \cdot 8 \mathrm{mEq} / 1$, on the day of death. Oedema had been present for 24 hours.

Plasma Electrolyte Levels. The concentration of electrolytes in plasma was usually estimated daily, levels having been obtained initially and as soon after the operation as possible in the more severely dehydrated cases. A few low levels, for sodium, below $130 \mathrm{mEq} / \mathrm{l}$., chloride, below $95 \mathrm{mEq} / \mathrm{l}$, and potassium, below $3.8 \mathrm{mEq} / 1$., were recorded both in the early and later phases of treatment, indicating either electrolyte depletion due to insufficient salt replacement, or haemodilution. In either case the correct treatment is administration of more concentrated saline solutions at a slow rate guided 


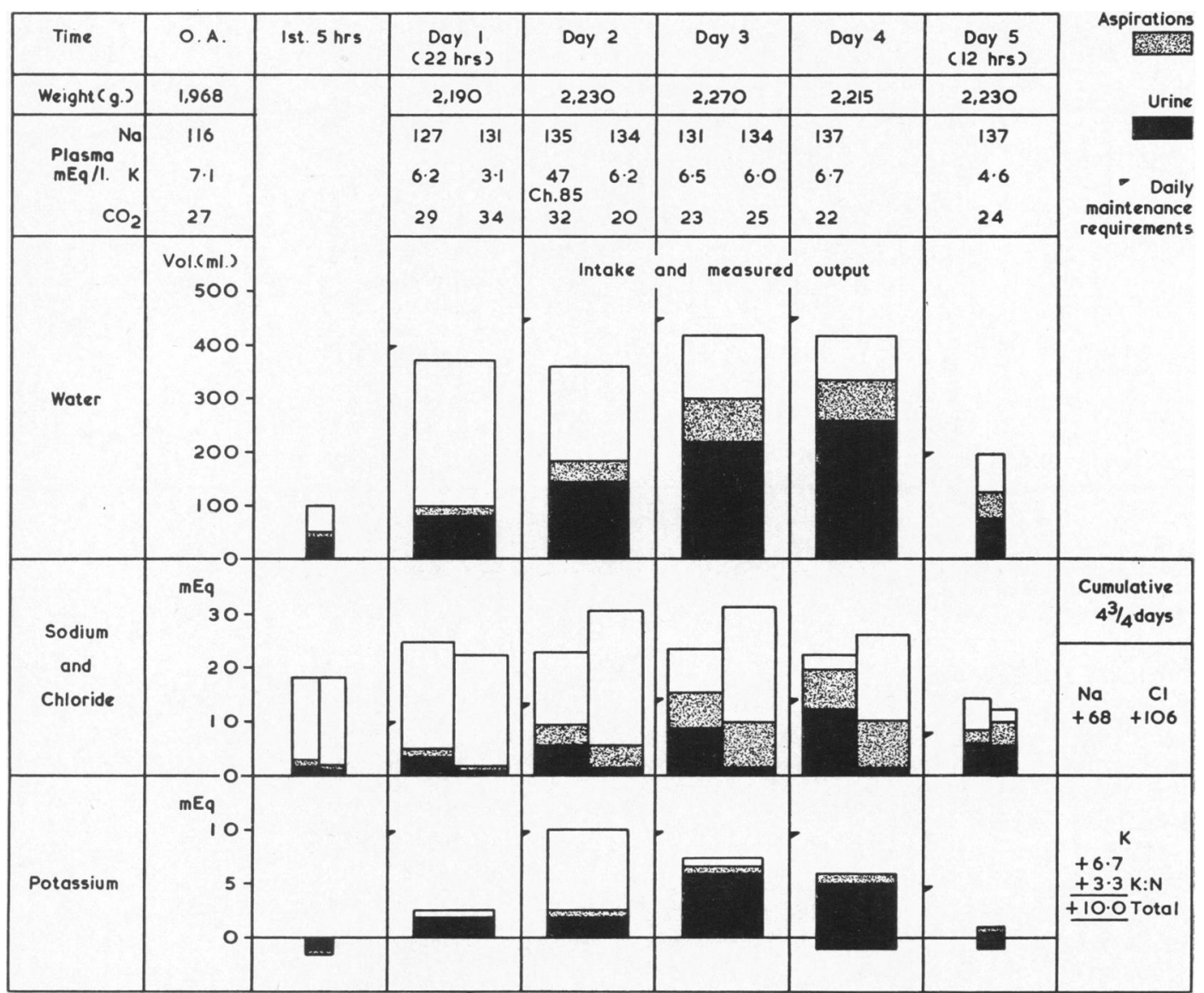

Fig. 2.-Retention of electrolytes following dehydration from duodenal obstruction in James H., age 8 days, who was born prematurely weighing $5 \mathrm{lb} .4 \mathrm{oz}$. $(2,380 \mathrm{~g}$.$) and who was jaundiced.$

by repeated estimation of the levels until they rise to within the normal range, but this was not always given. For example, James $H$., whose balance data are shown in Fig. 2, had three low or low normal levels while receiving intravenous infusions, and the deficit was not completely replaced until Day 5 or later. In retrospect, therefore, a higher intake of sodium from more concentrated solutions should have followed the initial infusion. Depletion of electrolytes is assumed in this and in the other patients with low plasma levels, since these levels did not coincide with oedema and excessive gain in weight, except in the premature infant who died.

No high sodium and chloride levels were recorded. A few high potassium levels, above $6.5 \mathrm{mEq} / \mathrm{l}$., were observed, but these always coincided either with a phase of nitrogen retention following oliguria (sometimes evidenced by high blood urea levels), or with increasing jaundice. The higher levels were near the toxic range, about $8 \mathrm{mEq} / \mathrm{l}$, , but they fell with later treatment and signs of intoxication were not observed. Unless the patient is jaundiced therefore, an initial high plasma level does not contraindicate the addition of potassium to the solutions for infusion when he begins to pass urine freely. If possible, the level should be estimated again at this stage.

Balance Studies. Since none of the five infants studied gained weight above their birth weight or had high plasma sodium or chloride levels during the periods studied, it is assumed that they were not overloaded with water or salt. Fig. 2 shows the day-to-day balance data, exemplified in James $\mathbf{H}$. The results are set out, as for the older subjects studied previously (Young et al., 1959). It will be 
TABLE 4

INITIAL DEFICIT OF ELECTROLYTES IN SIX CASES ESTIMATED FROM POSITIVE BALANCES DURING TREATMENT

\begin{tabular}{|c|c|c|c|c|c|c|c|c|c|}
\hline \multirow[t]{2}{*}{ Site } & \multirow[t]{2}{*}{ Subject } & \multirow{2}{*}{$\begin{array}{c}\text { Age on } \\
\text { Arrival } \\
\text { (days) }\end{array}$} & \multirow{2}{*}{$\begin{array}{c}\text { Birth } \\
\text { Weight } \\
\text { (kg.) }\end{array}$} & \multicolumn{2}{|c|}{$\begin{array}{l}\text { Weight Loss } \\
\text { (approx.) }\end{array}$} & \multicolumn{3}{|c|}{$\begin{array}{c}\text { Positive Balances* } \\
\text { (mEq/kg. birth weight) }\end{array}$} & \multirow{2}{*}{$\begin{array}{c}\text { Duration of } \\
\text { Investigation } \\
\text { (days) }\end{array}$} \\
\hline & & & & kg. & $\%$ & $\mathbf{N a}$ & $\mathbf{K}$ & $\mathrm{Cl}$ & \\
\hline Oesophagus & P.B. & 5 & $3 \cdot 32$ & $0 \cdot 520$ & 16 & $\begin{array}{c}5 \\
(16)\end{array}$ & $\stackrel{4}{(13) I n c .}$ & Not done & $\underset{\substack{1 \frac{1}{2} \\
\text { Pre-operative }}}{ }$ \\
\hline \multirow{5}{*}{ Duodenum } & M.J. & 2 & $3 \cdot 35$ & $0 \cdot 360$ & 11 & \multirow{5}{*}{$\begin{array}{l}12 \\
(40) \\
13 \\
(44) \\
11 \\
(17) \text { Inc. } \\
17 \\
(36) \text { Inc. } \\
29 \\
(68) \text { Inc. }\end{array}$} & \multirow{5}{*}{$\begin{array}{l}1 \cdot 3 \\
(4 \cdot 3)+\text { Inc. } \\
1 \cdot 5 \\
(5) \text { Inc. } \\
3 \cdot 5 \\
(5 \cdot 4) \text { Inc. } \\
6 \\
(13) \text { Inc. } \\
4 \cdot 2 \\
(10)\end{array}$} & \multirow{5}{*}{$\begin{array}{l}10 \\
(35) \\
13 \\
(42) \\
12 \\
(18) \text { Inc. } \\
22 \\
(47) \text { Inc. } \\
44 \\
(106) \text { Inc. }\end{array}$} & \multirow{5}{*}{ 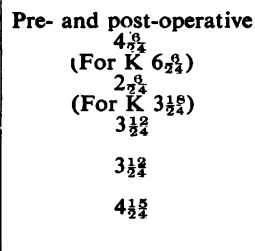 } \\
\hline & & 3 & $3 \cdot 27$ & & & & & & \\
\hline & B.P. & 4 & $1 \cdot 56$ & $0 \cdot 212$ & 14 & & & & \\
\hline & M.D. & 6 & $2 \cdot 15$ & 0.475 & 22 & & & & \\
\hline & J.H. & 8 & $2 \cdot 38$ & 0.425 & 18 & & & & \\
\hline & & & & & Average . & 16 & $3 \cdot 3$ & 20 & \\
\hline
\end{tabular}

* Figures in parentheses are totals. Inc. = Incomplete, due to discontinuation before balance was negative.

†Inc. = Incomplete, due to lack of data for $K: \mathbf{N}$. If $\mathbf{K}$ deriving from protein katabolism is omitted, the apparent total cumulative positive $\mathrm{K}$ balances would diminish to: P.B.: 7·4, D.D.: 1·8, B.P.: 3·0, M.D.: 11·7, and J.H.: 6.7.

seen that the intake exceeded the measured output for water, sodium and chloride and also for potassium until Day 4. Since losses of salt by sweating in newborn infants are minimal, the cumulative positive balance of electrolytes is taken to be a measure of the initial deficits. It may be noted that after hydration is restored, the intake of water continued to exceed the output in the urine and by aspiration of gastro-intestinal contents by about $100 \mathrm{ml} . / \mathrm{day}$, an amount needed to cover the insensible losses from the skin and lungs. Among the results from the other cases not set out in detail, a second positive sodium and chloride balance, subsequent to a negative phase, was observed in M.J. and D.D., but only the initial positive phase was included in assessing their initial deficits, the later one being apparently due to augmentation of the 'pool' of intestinal secietions, proximal to the anastomosis.

Table 4 shows the initial deficits of sodium, potassium and chloride (derived from cumulative positive balances) in five newborn infants with duodenal obstruction and one with oesophageal atresia. Where no negative balances had been observed, as for sodium and chloride in B.P., M.D. and J.H., and for potassium in P.B., D.D., B.P. and M.D., these deficits may have been estimated before complete repair, for retention of electrolytes might have been greater if the amounts given at an earlier stage had been larger or if the periods of observation had been longer. Such results are therefore labelled incomplete. An average retention of $\mathrm{Na} 16, \mathrm{~K} 3.3$ and $\mathrm{Cl} 20 \mathrm{mEq} / \mathrm{kg}$. birth weight for the infants with duodenal obstruction is compared with $\mathrm{Na} 5$ and $\mathrm{K}$ more than $4 \mathrm{mEq} / \mathrm{kg}$. birth weight for the infant with oesophageal atresia. The deficits of electrolytes increased with delay in diagnosis and treatment, as might be expected from prolongation of starvation and gastro-intestinal loss. The patient with oesophageal atresia had had only small losses of saliva and mucus, which accounts for his initial deficit of sodium being very small compared with the rest. However, he had a relatively big deficit of potassium recorded and even this may have been underestimated since the observations were incomplete. Such a deficit is a parallel to Black, McCance and Young's (1944) observations on the losses of potassium by thirsting adults.

Composition of Gastro-intestinal Fluid. The composition of the aspirated gastro-intestinal fluid (collected for a 24-hour period or longer) in 13 cases is shown in Table 5. The material was derived from the infants in whom the collections were made for balance studies, and also from some not studied in the present series. It is apparent that the concentration of chlorides was a little higher than that of sodium and therefore the aspirated fluid was probably a mixture of gastric and duodenal secretions. The concentration is approximately twothirds that of plasma. The concentration of potassium was relatively very low, in agreement with Gamble's (1947) findings in adults.

Table 6 shows the 24-hour losses from aspiration of gastro-intestinal contents in four children with post-operative ileus, including M.J. and D.D. If 
TABLE 5

COMPOSITION OF ASPIRATED GASTRO-INTESTINAL FLUID IN 13 CASES

\begin{tabular}{|c|c|c|c|c|}
\hline $\begin{array}{c}\text { Site of } \\
\text { Obstruction }\end{array}$ & $\begin{array}{l}\text { No. of } \\
\text { Cases }\end{array}$ & Sodium & Potassium & Chloride \\
\hline $\begin{array}{l}\text { Duodenum } \\
\text { Jejunum } \\
\text { Ileum } \\
\text { Colon }\end{array}$ & $\begin{array}{l}6 \\
1 \\
4 \\
2\end{array}$ & $\begin{array}{l}82-115 \\
91 \\
92-98 \\
88-125\end{array}$ & $\begin{array}{c}\text { Eq/litre (ran } \\
7-17 \\
14 \\
11-17 \\
6-13\end{array}$ & $\begin{array}{c}114-134 \\
\overline{125} \\
124\end{array}$ \\
\hline
\end{tabular}

similar amounts of gastro-intestinal fluid were being lost through vomiting before surgery in our patients, then daily losses of this order over a period of several days would account for the large initial deficits indicated by the balance studies.

Urine Flow. Information about urine flow during and immediately after surgery for a 12-hour period or longer was obtained in nine patients. The rate of flow may be compared with the $3 \mathrm{ml}$./ $\mathrm{hr} / \mathrm{kg}$. body weight reported for normal infants on full milk feeds, either breast or artificially fed, on the seventh day of life (McCance and Widdowson, 1960) and with about $1-2 \cdot 7 \mathrm{ml} . / \mathrm{hr} . / \mathrm{kg}$. body weight for normal infants 4 to 7 days old on electrolyte solution observed by Cole and Paulsen. In the early days of life, while the milk is 'coming in',
TABLE 6

VOLUME AND AMOUNT OF ELECTROLYTES IN ASPIRATED GASTRO-INTESTINAL FLUID PER 24 HOURS IN FOUR CASES WITH POST-OPERATIVE ILEUS

\begin{tabular}{|c|c|c|c|c|c|c|c|}
\hline \multirow{2}{*}{$\begin{array}{l}\text { Sub- } \\
\text { ject }\end{array}$} & \multirow{2}{*}{$\begin{array}{l}\text { Birth } \\
\text { Weight } \\
\text { (kg.) }\end{array}$} & \multirow[t]{2}{*}{ Site } & \multirow{2}{*}{$\begin{array}{c}\text { Dura- } \\
\text { tion } \\
\text { (days) }\end{array}$} & \multirow{2}{*}{$\begin{array}{c}\text { Average } \\
\text { Volume } \\
24 \text { hrs. } \\
\text { (ml.) }\end{array}$} & \multicolumn{3}{|c|}{$\begin{array}{c}\text { Average per } \\
24 \text { Hours (mEq) }\end{array}$} \\
\hline & & & & & $\mathbf{N a}$ & $\mathbf{K}$ & $\mathrm{Cl}$ \\
\hline $\begin{array}{l}\text { M.J. } \\
\text { D.D. } \\
\text { N.C. } \\
\text { J.F. }\end{array}$ & $\begin{array}{l}3 \cdot 350 \\
3 \cdot 270 \\
4 \cdot 300 \\
3 \cdot 500\end{array}$ & $\begin{array}{l}\text { Duodenum } \\
\text { Duodenum } \\
\text { Jejunum } \\
\text { Colon }\end{array}$ & $\begin{array}{l}4 \cdot 25 \\
3 \cdot 75 \\
6 \\
3\end{array}$ & $\begin{array}{l}126 \\
118 \\
124 \\
147\end{array}$ & $\begin{array}{l}11 \cdot 4 \\
14 \cdot 3 \\
11 \cdot 0 \\
13 \cdot 0\end{array}$ & $\begin{array}{l}1 \cdot 1 \\
0.9 \\
1 \cdot 7 \\
1 \cdot 9\end{array}$ & $\begin{array}{c}16 \cdot 8 \\
15 \cdot 0 \\
14 \cdot 0 \\
-\end{array}$ \\
\hline
\end{tabular}

the normal range for rates of urine flow is lower, $0.3-0.7 \mathrm{ml} . / \mathrm{hr} . / \mathrm{kg}$., but there is no reason to suppose that higher rates are outside physiological limits.

Table 7 shows the results in seven cases (six from the present series) who appeared hydrated and were passing urine before operation, and in two, B.I. and I.P., who were operated on only two and three hours after intravenous therapy had been started, while they were still dehydrated and not passing urine. During the first 12 hours, the range for rate of urine flow was $0.5-1.6 \mathrm{ml} / \mathrm{hr} . / \mathrm{kg}$. body weight in all but one (M.J.) of the seven hydrated cases, but B.I. and I.P. passed no urine until six and 13 hours after operation. M.J.'s slow rate

TABLE 7

URINE FLOW AND RATE OF ELECTROLYTE EXCRETION DURING AND IMMEDIATELY AFTER SURGERY COMPARED WITH NORMAL NEWBORNS

\begin{tabular}{|c|c|c|c|c|c|c|c|c|}
\hline \multirow{3}{*}{ Subject } & \multirow{3}{*}{$\begin{array}{c}\text { Site of } \\
\text { Obstruction }\end{array}$} & \multirow{3}{*}{$\begin{array}{c}\text { Birth } \\
\text { Weight } \\
\text { (kg.) }\end{array}$} & \multirow{3}{*}{$\begin{array}{c}\text { Age } \\
\text { (days) }\end{array}$} & \multirow{3}{*}{$\begin{array}{l}\text { Duration of } \\
\text { Collection } \\
\text { (hrs.) }\end{array}$} & \multicolumn{4}{|c|}{ Urine Output } \\
\hline & & & & & \multirow{2}{*}{$\begin{array}{l}\text { Urine Flow } \\
\text { (ml./hr./kg. } \\
\text { birth weight) }\end{array}$} & \multicolumn{3}{|c|}{$\begin{array}{l}\text { Electrolyte Excretion Rate } \\
\text { (mEq/hr./kg. birth weight) }\end{array}$} \\
\hline & & & & & & $\mathrm{Na}$ & $\mathbf{K}$ & $\mathrm{Cl}$ \\
\hline $\begin{array}{c}\text { Normal } \\
\text { Diet } \\
\text { Breas } \\
\text { Cows }\end{array}$ & $\begin{array}{l}\text { Ispecified } \\
\text { milk } \\
\text { milk }\end{array}$ & & $\begin{array}{l}2 \\
7 \\
7\end{array}$ & $\begin{array}{l}24 \\
24 \\
24\end{array}$ & $\begin{array}{c}0 \cdot 5 \\
(0 \cdot 3-0 \cdot 7) \\
3 \cdot 2 \\
(2 \cdot 5-3 \cdot 9) \\
2 \cdot 9 \\
(2 \cdot 3-3 \cdot 4)\end{array}$ & $\begin{array}{c}0.009 \\
(0.002-0.016) \\
0 \cdot 074 \\
(0.020-0 \cdot 128) \\
0 \cdot 112 \\
(0.090-0 \cdot 134)\end{array}$ & $\begin{array}{c}0.020 \\
(0.010-0 \cdot 030) \\
0 \cdot 040 \\
(0 \cdot 012-0.067) \\
0.088 \\
(0.050-0 \cdot 126)\end{array}$ & $\begin{array}{c}0.016 \\
(0 \cdot 007-0 \cdot 026) \\
0 \cdot 085 \\
(0 \cdot 045-0 \cdot 128) \\
0 \cdot 124 \\
(0 \cdot 088-0 \cdot 160)\end{array}$ \\
\hline $\begin{array}{l}\text { A.D. } \\
\text { M.J. } \\
\text { D.D. } \\
\text { B.P. } \\
\text { M.D. } \\
\text { D.S. } \\
\text { J.H. } \\
\text { B.I. } \\
\text { I.P. }\end{array}$ & $\begin{array}{l}\text { Jejuno-ileal } \\
\text { Duodenum } \\
\text { Duodenum } \\
\text { Duodenum } \\
\text { Duodenum } \\
\text { Duodenum } \\
\text { Duodenum } \\
\text { Duodenum } \\
\text { Ileum }\end{array}$ & $\begin{array}{l}2 \cdot 50 \\
3 \cdot 35 \\
3 \cdot 27 \\
1 \cdot 56 \\
2 \cdot 15 \\
3 \cdot 22 \\
2 \cdot 38 \\
3 \cdot 10 \\
3 \cdot 62\end{array}$ & $\begin{array}{l}1 \\
2 \\
3 \\
4 \\
6 \\
6 \\
8 \\
2 \\
3\end{array}$ & $\begin{array}{r}8-16 \\
16-30 \\
0-12 \\
12-18 \\
2-14 \\
14-38 \\
0-12 \\
12-24 \\
3-9 \\
9-21 \\
0-16 \\
16-29 \\
0-12 \\
12-36 \\
6-18 \\
18-30 \\
3-13 \\
13-24\end{array}$ & $\begin{array}{c}1.6 \\
1 \cdot 8 \\
0.2 \\
1 \cdot 5 \\
0.8 \\
2.9 \\
0.5 \\
1 \cdot 1 \\
2 \cdot 1 \\
1 \cdot 1 \\
\text { Voiding } \times 3 \\
4 \cdot 3 \\
1 \cdot 2 \\
2.7 \\
0.9+ \\
2 \cdot 5 \\
\text { A few ml. } \\
\text { concentrated } \\
1 \cdot 5\end{array}$ & $\begin{array}{c}- \\
0.009 \\
0.048 \\
0.018 \\
0.112 \\
0.015 \\
0.018 \\
0.102 \\
0.035 \\
- \\
0.058 \\
0.093 \\
-\end{array}$ & $\begin{array}{c}- \\
0.008 \\
0.037 \\
0.023 \\
0.026 \\
0.007 \\
0.011 \\
0.053 \\
0.028 \\
- \\
0.017 \\
0.039 \\
-\end{array}$ & $\begin{array}{c}- \\
0.008 \\
0.032 \\
0.016 \\
0.152 \\
0.006 \\
0.011 \\
0 \cdot 127 \\
0.067 \\
- \\
0.009 \\
0.022 \\
-\end{array}$ \\
\hline
\end{tabular}

* Data for normal newborns (average and normal range) after McCance and Widdowson (1960) 
$0.2 \mathrm{ml} . / \mathrm{hr} . / \mathrm{kg}$. body weight, during the first period was associated with hyponatraemia and water retention, which is in keeping with an antidiuretic response, but could have been due to the administration of hypotonic saline to a salt-depleted subject leading to impairment of renal function or to a fall of blood pressure and glomerular filtration rate during operation. His rate of flow was $1.5 \mathrm{ml}$./hr./ $\mathrm{kg}$. body weight for the succeeding six hours and the rate increased subsequently.

These observations show that urine flow was usually well maintained after surgery, and that after hydration was restored intravenous infusions given at rates comparable with a normal oral intake did not overload the body fluids. However, this response should only be expected if the intake of electrolytes is carefully prescribed from the outset according to the history, the serum electrolyte levels, changes in body weight, etc., and if infusions given at the time of operation are carefully regulated from minute to minute.

Urinary Output of Electrolytes and Nitrogen. The urinary output of electrolytes and nitrogen in normal infants during the first three days has been shown to be approximately the same whether water was given or withheld, but if thirsting, the infants lost more weight (Hansen and Smith, 1953). A hypotonic electrolyte solution orally did not increase the output, that for sodium being of the order of 0.35 $\mathrm{mEq} / \mathrm{kg}$. $/ 24 \mathrm{hrs}$. or about $1 \mathrm{mEq}$ total daily (Colle and Paulsen, 1959). Infants aged 7 days on full milk feeds had higher outputs, with a range from $0 \cdot 49-3.07$ for breast-fed infants up to $3.21 \mathrm{mEq} / \mathrm{kg}$./ $24 \mathrm{hrs}$. for those receiving cows' milk, the intake being about 1 and $4 \mathrm{mEq} / \mathrm{kg}$. $/ 24 \mathrm{hrs}$. respectively (McCance and Widdowson, 1960). Table 7 shows these outputs of sodium, potassium and chloride expressed as $\mathrm{mEq} / \mathrm{kg}$./ $/ \mathrm{hr}$. for comparison with similar data from the cases in the present series after operation. It will be seen that the output of these cases varied from below the range for normal infants aged 7 days (although usually within the range for younger infants) to high normal levels. The outputs were low at low rates of urine flow, associated with retention during the periods of positive balance, but they became higher in each case at higher rates of urine flow and as the deficit was being replaced. As far as information is available, the kidneys in these infants were able to excrete sodium like those of normal infants and the anti-diuretic response to surgery leading to water retention was not observed.

For example, J.D. passed relatively more sodium in the urine on Day 2 than Day 1 and it increased further on Days 3 and 4 as the positive balances declined (Fig. 1). Big negative sodium balances, suggesting previous over-retention, were not observed, but the investigations should have been continued longer to clarify this point.

The nitrogen output in four cases with duodenal obstruction averaged $109 \mathrm{mg} . / \mathrm{kg} . / 24 \mathrm{hrs}$. for the observation period (range: $52-148 \mathrm{mg} . / \mathrm{kg} . / 24 \mathrm{hrs}$.), which is similar to the average of $91 \mathrm{mg}$. found by Colle and Paulsen in normal newborns aged 3 to 7 days who were given glucose and electrolyte solutions only.

The potassium to nitrogen ratio in the urine was higher in each case at the beginning of the observation period before potassium had been added to the solution given intravenously than that deriving from katabolized protein. This is in contrast to Rickham's (1957) observations. The excess potassium excreted was probably liberated during the preceding dehydration phase rather than as a result of injury at operation, since high ratios were observed even before surgery.

The patient with oesophageal atresia passed much more nitrogen $(377 \mathrm{mg} . / \mathrm{kg} . / 24 \mathrm{hrs}$.) in his urine than did those with duodenal atresia, but this was probably derived from accelerated katabolism due to pneumonia. After rehydration, the potassium to nitrogen ratio in his urine became lower than that from katabolized protein, in spite of administration of potassium salts. He was therefore replacing his losses by retaining all the potassium given parenterally together with some of that derived from katabolized protein breakdown. After rehydration, the potassium to nitrogen ratio in the urine of another patient (B.P.) shows that he also must have been retaining potassium derived from protein katabolism as well as from the solutions given.

\section{Discussion}

The increment of electrolytes to the body fluids indicated by the strongly positive balances found in the cases presented here can be interpreted in two ways: (1) obligatory retention from slow urinary excretion, or (2) retention to replace preceding losses. Part of the retention of electrolytes shown by the positive balance findings might be considered obligatory, for Colle and Paulsen found small positive balances in four normal newborns receiving hypotonic electrolyte solutions by mouth. This may have been due to limitation of urinary excretion, but one of the two infants weighed serially gained only $2 \mathrm{oz}$. $(0.07 \mathrm{~kg}$.) and the other lost $16 \mathrm{oz}$. $(0.45 \mathrm{~kg}$.) in five days. A slight rise in the concentration of electrolytes in the plasma must be supposed in the absence of gain in weight, but the 
plasma was not examined. In McCance and Widdowson's (1957) experiments, where much larger amounts of salt were fed to three premature infants and to newborn piglets, the subjects gained weight, developed oedema and, at the same time, increased the concentration of sodium and chloride in the plasma.

Retention for replacement as the main cause of the positive balances in our series of cases is suggested by the following evidence.

1. The body weight was no higher than the birth weight in any case at the end of the balance period, and subsequent loss of weight did not exceed 3-4 ounces. High concentrations of extracellular electrolytes in plasma were not recorded. Retention in excess of the body's needs for replacement causing expansion of the extracellular fluid therefore seems improbable.

2. When a negative followed a positive balance it was never large or sustained for long enough to suggest that much of the previously retained electrolyte was being excreted, but the duration of the observations in some cases was too short to exclude this trend.

3. During positive balance periods the high rates of urine flow, with lower concentrations of electrolytes than newborn kidneys can achieve, suggest that the retention was not due to inadequate renal excretion.

4. The measurement of large electrolyte losses in the aspirated gastro-intestinal fluids after operation demonstrates that had similar losses from vomiting occurred before operation, initial deficits of the order of the positive balances here recorded might well have been sustained. The higher positive balances of the older newborns supports this contention, for the deficits would have been increasing each day until diagnosis and treatment.

The urinary output of potassium at first exceeded amounts liberated by katabolism of protein (according to the ratio of potassium to nitrogen) in the four cases where data are available. After rehydration, when potassium salts were being given, the potassium derived from katabolized protein could have contributed by being available for repair, but the amount was only a small fraction of that retained. High levels of potassium in the plasma at the outset should not therefore be considered a contraindication to the addition of potassium to the solutions for repair, for this is needed as soon as a free flow of urine is established.

In the light of the results of the present investigations, the prospective plan (Table 1) for intravenous fluid therapy for newborn infants with intestinal obstruction requires some modification.
Initial infusions of $60 \mathrm{ml} . / \mathrm{kg}$. (30 ml./lb.) body weight consisting of half isotonic saline, which supply only $4.5 \mathrm{mEq}$ of $\mathrm{Na} / \mathrm{kg}$. body weight, are unlikely to replace the initial deficits, especially of the more severely depleted cases whose treatment has been delayed until the age of 5 days or longer. Even if this infusion is changed to contain in part isotonic saline (as recommended if low plasma $\mathrm{Na}$ and $\mathrm{Cl}$ levels have been determined) it will sometimes contain insufficient salt for replacement. In younger, less depleted patients, replacement may be completed satisfactorily by the amount of sodium chloride in maintenance infusions of one-fifth isotonic saline, together with increments from the isotonic saline solution usually given in equal volume to that of aspirated gastro-duodenal fluid, for it has been shown that the aspirate contains about $100 \mathrm{mEq} / \mathrm{l}$. sodium and chloride compared with the $150 \mathrm{mEq} / \mathrm{l}$. in isotonic saline. The larger deficits which must be assumed in older newborns indicate that initial infusions of greater volume should be given, e.g. $90-120 \mathrm{ml} / \mathrm{kg}$. body weight over six to eight hours. It may be wise to delay surgery for this, or if not, an infusion of half isotonic saline for repair and maintenance should be continued at a slower rate after surgery, e.g. to supply $120 \mathrm{ml} . / \mathrm{kg}$. (60 ml./lb. body weight) in 24 hours, which is about the volume used for maintenance infusions in a 5-day-old baby. Isotonic in place of the hypotonic saline should be given if low plasma sodium and chloride levels are found and the levels repeated at six- to 12-hour intervals to guide the concentration of the solution used. After a free urine flow is established, potassium salts should be added in the same way as for the weaker solutions of saline used for maintenance. The guidance of repeated estimations of the plasma electrolyte levels is extremely valuable at this stage and should be obtained whenever possible, and in any case where diuresis is delayed.

It should always be supposed that the deficits of infants with low intestinal, as compared with duodenal, obstruction will be greater at an earlier stage and that they may be partially masked because intestinal pooling occurs rather than the copious vomiting of high intestinal obstruction. Also, that these deficits are best replaced by a mixture of sodium salts both in the isotonic and the half isotonic solutions, e.g. two parts sodium chloride and one part $\mathrm{Na}$ lactate instead of the saline solution alone.

Maintenance Infusions. Glucose in hypotonic salt solutions must be prescribed cautiously for newborn infants (especially if premature) whose 
urine flow is poor. Oliguria may be due to incomplete repair of depletion, or to capillary damage with a tendency to oedema, associated with stress at birth, infection or hypothermia. In either case, hypotonic solutions will precipitate a fall in the plasma sodium level and consequent deterioration in renal function. Judgement based upon repeated clinical examination and assessment of urine flow and plasma electrolyte levels must then guide treatment from hour to hour. The criteria warranting safe use of hypotonic (one-fifth isotonic) saline or salt lactate with added $\mathrm{K}$ salts to supply $20 \mathrm{mEq} /$ litre as a maintenance infusion in newborn infants are as follows.

1. Restoration of body weight to near the birth weight and clinical evidence of rehydration.

2. Return of good urine flow as judged by passage of a good volume of pale urine without deposit.

3. Normal concentrations of sodium and potassium in the plasma. If the plasma sodium level falls below $130 \mathrm{mEq} / \mathrm{l}$, isotonic saline solution should be given at a slow rate until it rises. Unless the plasma potassium level is raised, potassium may be added to this solution and will help to maintain the urine flow.

Careful selection of the concentration of sodium chloride in the solutions to be used, together with the judicious use of potassium salts, will usually avoid the complications from either over-retention of sodium or water intoxication.

Prevention and treatment of hyponatraemia is emphasized because of the associated risk of convulsions which are difficult to control. Twitching may also be due to hypocalcaemia, examples of which were recorded in the earlier part of this paper. Twitching due to neonatal hypoglycaemia is avoided by the recommended use of $5 \%$ glucose with the electrolyte solutions.

\section{Summary and Conclusions}

A consecutive series of 24 newborn infants with intestinal obstruction has been given parenteral fluids during the pre- and post-operation period according to a plan devised for older infants and children, adapted for the first week of life. The treatment aims to replace abnormal losses, both preceding and following the operation and to maintain the volume and composition of the body fluids with emphasis on the importance of maintaining a free flow of urine.

Assessment of the results is based upon (i) the clinical course of all the 24 patients in the series, of whom 21 survived and three died, but in only one was the cause of death associated with electro- lyte imbalance; (ii) balance studies in five infants with duodenal obstruction; and (iii) analysis of (a) aspirated gastro-intestinal fluid and (b) the urine output in these and further cases.

The average initial deficits deduced from the balance data were $\mathrm{Na} 16, \mathrm{~K} 3 \cdot 3$, and $\mathrm{Cl} 20 \mathrm{mEq} / \mathrm{kg}$. body weight in the cases of duodenal obstruction, compared with much smaller deficits of sodium and chloride in an infant with oesophageal atresia investigated for comparison. The volume and composition of the aspirated gastro-intestinal fluid show that daily losses from vomiting could have led to these deficits.

Neither an immediate antidiuretic response, nor retention of sodium following surgery were apparent from observations of urinary volume and of electrolyte output, except perhaps in one premature infant.

The amounts of sodium chloride in the solutions recommended in the plan for the early phase of treatment are insufficient to replace the average deficits. Since the cumulative losses increase with delay in treatment and probably also with obstruction at lower levels of the small bowel, the amounts of sodium salts given for replacement should be judged accordingly. The treatment, especially in premature infants with a tendency to oedema, must be guided by frequent reappraisal (clinical examination, serial weight, urine output and estimate of plasma electrolyte levels) to avoid the risks of inadequate replacement on the one hand and of overloading on the other.

In conclusion, since the sodium and chloride deficits of infants with severe dehydration associated with intestinal obstruction is likely to be higher than previously supposed, the need for replacement of larger deficits should be assumed at the outset of treatment. As the extent of the deficits cannot be closely predicted, frequent reappraisal is essential so that the initial plan can be modified where necessary.

The authors are grateful to the consultant medical staff of the Queen Elizabeth Hospital for Children for permission to study cases under their care, and to the junior staff for their help. They also wish to thank the nursing staff for their willing co-operation and skilled assistance throughout the investigation. They are greatly indebted to Dr. B. Levin, pathologist-in-charge, and Mr. V. G. Oberholzer, senior biochemist to the hospital, for the laboratory investigations. The British Council and Messrs. Cow and Gate Ltd., generously supported this work by providing A.P. with a full-time research grant for three and four months respectively.

\section{REFERENCES}

Black, D. A. K. (1957). The breakdown of the water equilibrium in disease. Proc. Nutr. Soc., 16, 123.

McCance, R. A. and Young, W. F (1944). A study of dehydration by means of balance experiments. J. Physiol. (Lond.), $102,406$. 
Calcagno, P. L., Rubin, M. I. and Singh, W. S. A. (1955). The influence of surgery on renal function in infancy. I. The effect of surgery on the postoperative renal excretion of water-The influence of dehydration. Pediatrics, 16, 619.

Colle, E. and Paulsen, E. P. (1959). Response of the newborn infant to major surgery. I. Effects on water, electrolyte and nitrogen balances. ibid., 23, 1063.

Dean, R. F. A. and McCance, R. A. (1949). The renal responses of infants and adults to the administration of hypertonic solutions sodium chloride and urea. J. Physiol. (Lond.), 109, 81 .

Gamble, J. L. (1947). Chemical Anatomy, Physiology and Pathology of Extra-cellular Fluid. Harvard University Press, Cambridge, Massachusetts.

Grob, M. (1960). Intestinal obstruction in the newborn infant. Arch. Dis. Childh., 35, 40.

Arch. Dis. Childh., 35, 40.
Gross, R. E. (1953). The Surgery of Infancy and Childhood, p. 21. Saunders, Philadelphia.

Hansen, J. D. L. and Smith, C. A. (1953). Effects of withholding fluid in the immediate postnatal period. Pediatrics, 12, 99.

Heller, H. (1951). The water metabolism in newborn infants and animals. Arch. Dis. Childh., 26, 195.

Holliday, M. A., Wallace, W. M. and Stapleton, T. Unpublished data quoted by Stapleton, T. (1958). In Modern Trends in Paediatrics (2nd series), p. 285, ed. A. Holzel and J. P. M. Paediatrics (2nd series), p. 285,

Le Quesne, L. P. (1957). Fluid Balance in Surgical Practice. Lloyd-Luke, London.

- and Lewis, A. A. G. (1953). Postoperative water and sodium retention. Lancet, 1, 153 .
Lowe, C. U., Rourke, M., MacLachlan, E. and Butler, A. M. (1950). Use of parenteral potassium therapy in surgical patients. Pediatrics, 6, 183.

McCance, R. A. (1948). Renal function in early life. Physiol. Rev., 28, 331 .

and Widdowson, E. M. (1954). The influence of events during the last few days in utero on tissue destruction and renal function in the first two days of independent life. Arch. Dis. Childh., $29,495$.

fluids. Acta paediat. (Uppsala), 46, 337.

int (1960). Renal aspects of acid base control in the newly born. 1. Natural development. ibid., 49, 409.

Rickham, P. P. (1957). The Metabolic Response to Neonatal Surgery. Harvard University Press, Cambridge, Massachusetts.

Santulli, T. V. (1954). Intestinal obstruction in the newborn infant. J. Pediat., 44, 317.

Swain, V. A. J., Peonides, A. and Young, W. F. (1963). Prognosis after resection of small bowel in the newborn. Arch. Dis. Childh., 38, 103 . Swenson, O. (1958). Pediatric Surgery, p. $310 . \quad$ Appleton-Century-
Crofts, New York.

Wilkinson, A. W. (1960). Body Fluids in Surgery, 2nd ed. Livingstone, Edinburgh and London.

Young, W. F., McIntosh, J., Swain, V. and Levin, B. (1959). Parenteral fluid therapy for children undergoing major abdominal surgery. Brit. J. Surg., 47, 261. 